\title{
Is Uric Acid elevation a random finding or a causative agent of diabetic nephropathy?
}

\section{SUMMARY}

OBJECTIVE: In this study, we aimed to analyze the relationship between serum uric acid (UA) and microalbuminuria as a marker of renal injury in type 2 diabetes mellitus.

METHODS: A total of 100 patients with type 2 diabetes mellitus were enrolled in the study. Participants were divided into two groups according to the urinary microalbumin/creatinine ratio: diabetic nephropathy and non-nephropathy group. UA and microalbuminuria were compared between the study groups.

RESULTS: Serum UA levels of diabetic nephropathy patients were significantly higher than those in the non-nephropathy group (UA in patients with diabetic nephropathy groups: 6.3 (1.82) mg/dl, UA in patients of the non-nephropathic group: 4.85 (1.92) mg/dl) ( $p<0.001)$. There was a correlation between microalbuminuria and UA ( $r=0.238)$. This correlation was statistically significant $(p=0.017)$.

CONCLUSION: UA levels may be an important predictor of nephropathy in diabetic patients.

KEYWORDS: Uric acid. Diabetic nephropathies. Albuminuria.

\section{INTRODUCTION}

Diabetic renal disease is the most common cause of end-stage renal failure. ${ }^{1}$ Experimental and clinical studies indicate that inflammation is a cardinal pathogenetic mechanism in diabetic nephropathy.,3 The elements of the diabetic environment (immune complexes, hyperglycemia, and advanced glycation end-products) stimulate kidney cells, causing the extricate of chemokines and regulation of cell adhesion molecules. ${ }^{4}$ These conditions facilitate renal infiltration by lymphocytes and monocytes in diabetic kidneys and the secretion of reactive oxygen products. ${ }^{4}$
During uric acid (UA) synthesis, oxidants are produced that can play a pivotal role in renal injury. ${ }^{5}$ It has been reported that free oxygen radicals driven by UA have important effects in endothelial dysfunction by inducing inflammation, which leads to the development of diabetic nephropathy. ${ }^{6}$ The relationship between UA and endothelial dysfunction, oxidative stress, nitric oxide activity, and smooth muscle cell proliferation has been reported..$^{7-9}$ Furthermore, it is still under investigation whether UA is an independent risk factor for macrovascular disease in diabetics. ${ }^{10}$ 
Microalbuminuria in subjects with type 2 diabetes mellitus is known to be a marker of the last phase in which renal injury can be reversed. We concluded that UA might be an easy and beneficial index of oxidative stress, and elevated UA might be a marker of renal injury. We aimed to study the association between microalbuminuria and serum UA levels as a marker of renal injury in diabetic patients.

\section{METHODS}

Our study was performed retrospectively after approval by the Ethics Committee of the Abant İzzet Baysal University Medical Faculty (Ethical approval number: 2018/196). A total of 100 patients with type 2 diabetes mellitus (51 female, 49 male) who were admitted to the internal medicine clinic between December 2017 and April 2018 were included. Participants were divided into groups according to the urinary microalbumin/creatinine ratio: diabetic nephropathy and non-nephropathy. Patients' age, gender, waist circumference (WC), body mass index (BMI), duration of diabetes, systolic blood pressures (SBP), and diastolic blood pressures (DBP) were recorded. The UA, fasting blood glucose (FBG), total cholesterol, triglyceride, low-density protein (LDL), high-density lipoprotein (HDL), glycated hemoglobin (HbA1c), creatinine, urea, glomerular filtration rate (GFR), and microalbumin and creatinine in spot urine were recorded. Microalbuminuria was calculated using formula [spot urine microalbumin (gr/l)/spot urine creatinine $\mathrm{g} / \mathrm{dl})] \mathrm{x} 100$. None of the patients had a history of gout and thiazide diuretics, and allopurinol users, malignant conditions, congenital disorders associated with elevated UA were not included in the study.

\section{Statistical analysis}

Statistical data were analyzed using SPSS software (SPSS 15.0 for Windows, IBM, Chicago, IL, USA). Descriptive statistics were presented as Median (minmax) and Mean \pm SD. Normal distribution of continuous variables was evaluated by Kolmogorov-Smirnov tests. Homogeneous variables were analyzed using the Student t-test, and non-homogenously variables were analyzed using the Mann-Whitney U-test. The receiver operating characteristic (ROC) curve analyses were performed to determine UA cut-off values, the area under the curve (AUC), sensitivity, and specificity to predict diabetic nephropathy. Correlation analysis was conducted by Pearson correlation test. $\mathrm{P}<0.05$ was accepted as statistically significant.

\section{RESULTS}

A total of 100 subjects enrolled in the study. The nephropathy group had 36 (36\%) patients, and the non-nephropathy 64 (64\%). In the nephropathy group, 17 patients were women, and 19 were men. There were 34 women and 30 men in the non- nephropathy group $(p=0.57)$. The mean age of the patients in the diabetic nephropathy and non-nephropathy groups were $62.4 \pm 7.6$ and $59.3 \pm 9.3$ years, respectively $(p=0.1)$. There was no significant difference between WC, BMI, SBP, and DBP between the study groups ( $p>0.05$ for all) (Table 1).

FBG was 225.5(62-466) $\mathrm{mg} / \mathrm{dl}$ in the diabetic nephropathy group, and $135.5(72-394) \mathrm{mg} / \mathrm{dl}$ in the non-nephropathy group ( $\mathrm{p}<0.001)$. HbA1c was 9.6 (6.1-15.5) in the diabetic nephropathy group, and 6.9 (6.1-10.8) in the non-nephropathy group; there was a statistically significant difference between the groups

TABLE 1. DEMOGRAPHIC CHARACTERISTICS AND LABORATORY DATA OF THE STUDY GROUP.

\begin{tabular}{|c|c|c|c|}
\hline & $\begin{array}{l}\text { Diabetic ne- } \\
\text { phropathy group }\end{array}$ & $\begin{array}{l}\text { Diabetic non-ne- } \\
\text { phropathy group }\end{array}$ & $p$ \\
\hline \multicolumn{4}{|c|}{ Mean \pm StD } \\
\hline Age (year) & $62.4 \pm 7.6$ & $59.3 \pm 9.3$ & 0.1 \\
\hline $\begin{array}{l}\text { Glomerular filtration } \\
\text { rate }(\%)\end{array}$ & $73 \pm 20$ & $83.8 \pm 15.5$ & 0.003 \\
\hline \multicolumn{4}{|c|}{ Median (min-max) } \\
\hline $\begin{array}{l}\text { Systolic Blood Pres- } \\
\text { sure }(\mathrm{mm} / \mathrm{Hg})\end{array}$ & $130(120-180)$ & $130(100-180)$ & 0.86 \\
\hline $\begin{array}{l}\text { Diastolic Blood Pres- } \\
\text { sure }(\mathrm{mm} / \mathrm{Hg})\end{array}$ & $80(70-105)$ & $80(60-100)$ & 0.41 \\
\hline $\begin{array}{l}\text { Body Mass Index (kg/ } \\
\mathrm{m} 2)\end{array}$ & $30.5(21.5-48.3)$ & $30.3(22.3-49.3)$ & 0.85 \\
\hline $\begin{array}{l}\text { Waist Circumference } \\
(\mathrm{cm})\end{array}$ & $105.5(84-135)$ & $103.5(77-144)$ & 0.77 \\
\hline Uric acid $(\mathrm{mg} / \mathrm{dl})$ & $6.3(4.2-9.6)$ & $4.9(3-8.5)$ & $<0.001$ \\
\hline Hemoglobin A 1C (\%) & $9.6(6.1-15.5)$ & $6.9(6.1-10.8)$ & $<0.001$ \\
\hline $\begin{array}{l}\text { Fasting Blood Glu- } \\
\text { cose }(\mathrm{mg} / \mathrm{dl})\end{array}$ & $225.5(62-466)$ & $135.5(72-394)$ & $<0.001$ \\
\hline $\begin{array}{l}\text { Low-Density Lipo- } \\
\text { protein }(\mathrm{mg} / \mathrm{dl})\end{array}$ & $106(102-259)$ & $118(90-189)$ & 0.81 \\
\hline $\begin{array}{l}\text { Triglycerides } \\
(\mathrm{mg} / \mathrm{dl})\end{array}$ & $150(59-600)$ & $145(46-615)$ & 0.42 \\
\hline $\begin{array}{l}\text { High Dansity Lipo- } \\
\text { protein (mg/dl) }\end{array}$ & $41(25-73)$ & $46(25-79)$ & 0.011 \\
\hline Creatinine (mg/dl) & $0.92(0.65-1.2)$ & $0.83(0.63-1.2)$ & 0.009 \\
\hline $\begin{array}{l}\text { Microalbuminuria } \\
\text { (mg/gr) }\end{array}$ & $48.2(531.4-624)$ & $10.7(3-29)$ & $<0.001$ \\
\hline
\end{tabular}


( $<<0.001)$. Serum creatinine level was $0.92(0.65-1.2)$ $\mathrm{mg} / \mathrm{dl}$ in the diabetic nephropathy, and $0.83(0.63-1.2)$ $\mathrm{mg} / \mathrm{dl}$ in the non-nephropathy group ( $\mathrm{p}=0.009)$; GFR was significantly higher in the diabetic nephropathy group ( $\mathrm{p}=0.003$ ) (Table 1). HDL-cholesterol was 41 $(25-73) \mathrm{mg} / \mathrm{dl}$ in the nephropathy group, and $46(25-$ 79) $\mathrm{mg} / \mathrm{dl}$ in the non-nephropathy group ( $\mathrm{p}=0.003$ ). There were no significant differences in triglyceride and LDL-cholesterol levels between the study groups ( $>0.05$ for all) (Table 1). The UA in patients in the diabetic nephropathy and non-nephropathic groups were $6.3(4.2-9.6) \mathrm{mg} / \mathrm{dl}$ and $4.9(3-8.5) \mathrm{mg} / \mathrm{dl}$, respectively; this difference was statistically significant $(p<0.001)$.

In the study group, the correlation between microalbuminuria and UA was examined. There was a correlation between microalbuminuria and $\mathrm{UA}(\mathrm{r}=0.238)$. This correlation was statistically significant $(\mathrm{p}=0.017)$. A ROC curve analysis was used to determine HbA1C, FBG, and UA in detecting diabetic nephropathy. The best cut-off values for UA was $5.2 \mathrm{mg} / \mathrm{dl}$ (AUC=0.749, $\mathrm{p}<0.001)($ Figure 1). According to ROC analysis, UA predicted diabetic nephropathy with $80.6 \%$ sensitivity and $64.1 \%$ specificity. ROC curve analysis of HbA1c and FBG are shown in figure 1.

\section{DISCUSSION}

This study showed a relationship between diabetic nephropathy and UA. It was found that the microalbuminuria levels were also increased due to the oxidants formed by the increased UA level. Thus, in type

FIGURE 1. THE ROC CURVE OF URIC ACID, HBATC, FASTING BLOOD GLUCOSE, HDL-CHOLESTEROL, AND EGFR FOR DIABETIC NEPHROPATHY.

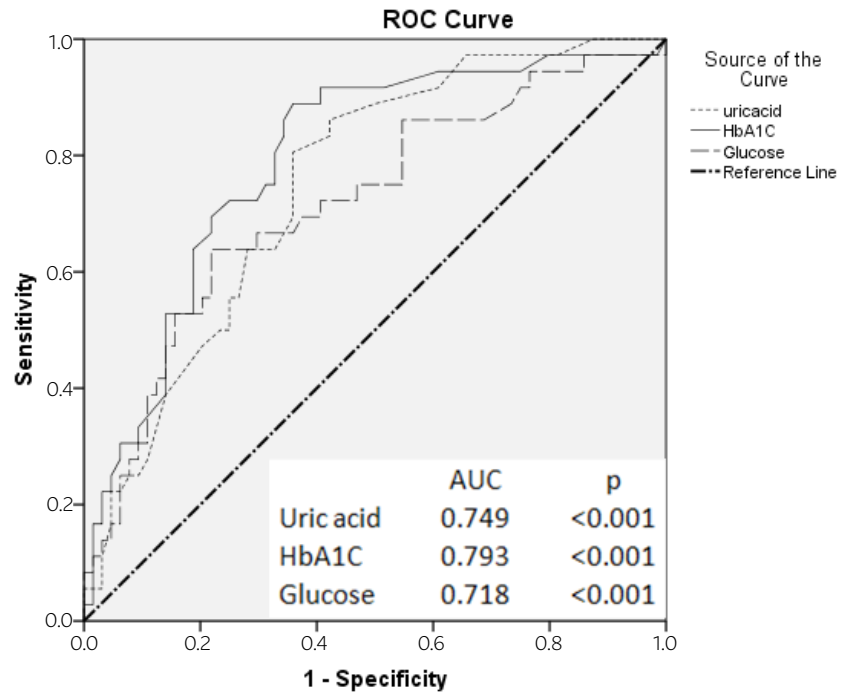

2 diabetic patients, the increased UA levels may be a marker for early detection of diabetic nephropathies, such as microalbuminuria.

Macrophages and $\mathrm{T}$ cells accumulate in the interstitium, in the initial phase of the diabetic nephropathy. ${ }^{4}$ These $\mathrm{T}$ cells and macrophages secrete proinflammatory cytokines such as tumor necrosis factor-a (TNF-a) and interleukin-1 (IL-1). Advanced glycation end-products and hyperglycemia stimulate chemokine production in renal cells. ${ }^{4}$ These increased chemokines then direct the migration of additional leukocytes to the kidneys and form an inflammatory cycle that causes renal damage. These events enable renal infiltration of lymphocytes and monocytes in the kidneys and facilitate the secretion of destructive molecules such as reactive oxygen products. ${ }^{4}$

UA is produced by xanthine oxidase and is a product of purine degradation. ${ }^{11}$ While UA is synthesized, oxidants are produced that can cause renal dysfunction and cardiovascular disease. ${ }^{5}$ It has been reported that UA plays an important role in endothelial dysfunction by inducing inflammation with these oxygen-radical products and may lead to the development of diabetic nephropathy. ${ }^{6}$ Hyperuricemia-induced endothelial dysfunction has been suggested to reduce renal perfusion, along with glomerular hypertension and renal hypertrophy, by stimulating afferent vascular smooth muscle cell proliferation, which suggests that increased UA levels are a detrimental factor in the kidneys. ${ }^{10,12,13}$

One study found that serum UA correlated significantly with diabetic nephropathy and that the serum UA level was found to be an important cause of nephropathy in diabetic patients. ${ }^{14}$ A study by Neupane et al. ${ }^{15}$ reported that serum UA levels match urinary albumin excretion. Another study showed a positive correlation between microalbuminuria and serum UA. Therefore, it was concluded that serum UA and microalbuminuria levels are early diagnostic markers for cardiovascular and renal diseases. In addition, it has been reported that it is very useful to identify the prognosis of the disease in diabetic patients. ${ }^{16}$ In our study, UA and microalbuminuria had weak correlations and were not statistically significant, whereas UA levels were statistically significantly higher in nephropathic patients.

Elevated serum UA is related to renal injury by glomerular hypertrophy and sclerosis, ${ }^{1}$ but there are controversial reports on the association between UA levels and chronic renal disease in the literature. ${ }^{17-19}$ 
The independent role of mild hyperuricemia on the progression of renal disease is uncertain at present. ${ }^{20}$ Severe elevated serum UA levels have been found to be an independent risk factor for renal damage. ${ }^{21}$ Serum UA levels in our study were mildly elevated and associated with diabetic nephropathy.

Reactive oxygen radicals are formed during UA production, and it is reported that UA may be a simple and beneficial marker of increased oxidative stress. ${ }^{22}$ With the use of allopurinol, UA levels were reduced, as were the harmful effects of UA. ${ }^{23}$ With the decrease in UA levels, were also reported suppression of the aldosterone system of renin-angiotensin, increased nitric oxide, reduced oxidative stress, improved endothelial function, and decreased levels of markers for urinary inflammation. $^{23}$

Hyperuricemia is an individual risk factor for the development of chronic renal disease in patients with Type 2 diabetes and normal renal function. ${ }^{24}$ Most patients with type 2 diabetes mellitus have been found to have manifested renal glomerular and tubular damage even before the occurrence of microalbuminuria. ${ }^{25}$ Prevention or reduction of hyperuricemia in diabetic patients may prevent nephropathy progression.

Limitations of the present study are its retrospective design and relatively small study population. However, increased UA levels in diabetic nephropathy are important results that may contribute to the current literature.

\section{CONCLUSION}

The effect of elevated UA levels on renal damage is evident. In conclusion, UA elevation is not a random finding; it is correlated with microalbumin levels in patients with diabetic nephropathy. UA levels may be an important predictor of nephropathy in diabetic patients.

\section{RESUMO}

OBJETIVO: O objetivo deste estudo foi analisar a relação entre o ácido úrico sérico ( $A U$ ) e a microalbuminúria como marcador de lesão renal no diabetes mellitus tipo 2.

MÉTODOS: Um total de 100 pacientes com diabetes mellitus tipo 2 foram inscritos no estudo. Os grupos de estudo foram divididos em dois, de acordo com a relação microalbumina/creatinina na urina: nefropatia diabética e grupo não nefropático. UA e microalbuminúria foram comparados entre os grupos de estudo.

RESULTADOS: Os níveis séricos de AU de pacientes com nefropatia diabética foram significativamente maiores do que o grupo sem nefropatia (AU em pacientes com grupos de nefropatia diabética: 6,3 (1,82) mg/dl, AU em pacientes com grupos não nefropáticos: 4,85 (1,92) $\mathrm{mg} / \mathrm{dl})(p<0,001)$. Houve correlação entre microalbuminúria e $\mathrm{A} \cup(r=0,238)$. Essa correlação foi estatisticamente significativa ( $p=0,017)$.

CONCLUSÃO: Os níveis de AU podem ser um importante preditor de nefropatia em pacientes diabéticos.

PALAVRAS-CHAVE: Ácido úrico. Nefropatias diabéticas. Albuminúria.

\section{REFERENCES}

1. Latif H, labal A, Rathore R, Butt NF. Correlation between serum uric acid level and microalbuminuria in type-2 diabetic nephropathy. Pak J Med Sci. 2017:33(6):1371-5.

2. Dalla Vestra M, Masiero A, Roiter AM, Saller A, Crepaldi G, Fioretto P. Is podocyte injury relevant in diabetic nephropathy? Studies in patients with type 2 diabetes. Diabetes. 2003;52(4):1031-5.

3. Chow FY, Nikolic-Paterson DJ, Ma FY, Ozols E, Rollins B], Tesch GH. Monocyte chemoattractant protein-1-induced tissue inflammation is critical for the development of renal injury but not type 2 diabetes in obese $\mathrm{db} / \mathrm{db}$ mice. Diabetologia. 2007;50(2):471-80.

4. Lim AK, Tesch GH. Inflammation in diabetic nephropathy. Mediators inflamm. 2012;2012:146154.

5. Muiesan ML, Agabiti-Rosei C, Paini A, Salvetti M. Uric acid and cardiovascular disease: an update. Eur Cardiol. 2016;11(1):54-9.

6. Cai W, Duan XM, Liu Y, Yu J, Tang YL, Liu ZL, et al. Uric acid Induces endothelial dysfunction by activating the HMGB1/RAGE signaling pathway. Biomed Res Int. 2017;2017:4391920.

7. Khosla UM, Zharikov S, Finch JL, Nakagawa, T, Roncal C, Mu W, et al. Hyperuricemia induces endothelial dysfunction. Kidney Int. 2005;67(5):1739-42.
8. Kanellis |, Kang DH. Uric acid as a mediator of endothelial dysfunction, inflammation, and vascular disease. Semin Nephrol. 2005;25(1):39-42.

9. Maxwell A), Bruinsma KA. Uric acid is closely linked to vascular nitric oxide activity: evidence for mechanism of association with cardiovascular disease. J Am Coll Cardiol. 2001;38(7):1850-8.

10. Yan D, Wang J, Jiang F, Zhang R, Wang T, Wang S, et al. A causal relationship between uric acid and diabetic macrovascular disease in Chinese type 2 diabetes patients: a Mendelian randomization analysis. Int | Cardiol. 2016;214:194-9.

11. Maiuolo J, Oppedisano F, Gratteri S, Muscoli C, Mollace V. Regulation of uric acid metabolism and excretion. Int | Cardiol. 2016;213:8-14.

12. Tseng $\mathrm{CH}$. Correlation of uric acid and urinary albumin excretion rate in patients with type 2 diabetes mellitus in Taiwan. Kidney Int. 2005;68(2):796-801.

13. Fukui M, Tanaka M, Shiraishi E, Harusato I, Hosoda H, Asano M, et al. Serum uric acid is associated with microalbuminuria and subclinical atherosclerosis in men with type 2 diabetes mellitus. Metabolism. 2008;57(5):625-9. 
14. Behradmanesh $S$, Horestani MK, Baradaran A, Nasri H. Association of serum uric acid with proteinuria in type 2 diabetic patients. J Res Med Sci. 2013;18(1):44-6

15. Neupane S, Dubey RK, Gautam N, Agrawal KK, Jayan A, Shrestha S, et al. Association between serum uric acid, urinary albumin excretion, and glycated hemoglobin in type 2 diabetic patient. Niger Med J. 2016;57(2):119-23.

16. Suryawanshi K, Jagtap P, Belwalkar G, Dhonde S, Nagane N, Joshi V. To study serum uric acid and urine microalbumin in type-2 diabetes mellitus. Int J Med Sci. 2015;2(3):24-9.

17. Suzuki K, Konta T, Kudo K, Sato H, Ikeda A, Ichikawa K, et al. The association between serum uric acid and renal damage in a community-based population: the Takahata study. Clin Exp Nephrol. 2013;17(4):541-8.

18. Weiner DE, Tighiouart H, Elsayed EF, Griffith JL, Salem DN, Levey AS. Uric acid and incident kidney disease in the community. J Am Soc Nephrol. 2008;19(6):1204-11.

19. Oh CM, Park SK, Ryoo JH. Serum uric acid level is associated with the development of microalbuminuria in Korean men. Eur ] Clin Invest. 2014;44(1):4-12.
20. Viazzi F, Leoncini G, Ratto E, Falqui V, Parodi A, Conti N, et al. Mild hyperuricemia and subclinical renal damage in untreated primary hypertension. Am J Hypertens. 2007;20(12):1276-82.

21. De Cosmo S, Viazzi F, Pacilli A, Giorda C. Ceriello A, Gentile S, et al; AMD-Annals Study Group. Serum uric acid and risk of CKD in type 2 diabetes. Clin J Am Soc Nephrol. 2015;10(11):1921-9.

22. Neves |A, Neves JA, Oliveira RCM. Biomarcadores de função endotelial em doenças cardiovasculares: hipertensão. J Vasc Bras. 2016;15(3):224-33.

23. Maahs DM, Caramori L, Cherney DZ, Galecki AT, Gao C, Jalal D, et al; PERL Consortium. Uric acid lowering to prevent kidney function loss in diabetes: the preventing early renal function loss (PERL) allopurinol study. Curr Diab Rep. 2013;13(4):550-9.

24. Zoppini G, Targher G, Chonchol M, Ortalda V, Abaterusso C, Pichiri I, et al. Serum uric acid levels and incident chronic kidney disease in patients with type 2 diabetes and preserved kidney function. Diabetes Care. 2012;35(1):99-104.

25. Zhang Y, Yang J, Zheng M, Wang Y, Ren H, Xu Y, et al. Clinical characteristics and predictive factors of subclinical diabetic nephropathy. Exp Clin Endocrinol Diabetes. 2015;123(2):132-8. 